\title{
Inguinal hernia incarceration as a form of intestinal tuberculosis
}

\begin{abstract}
We report the case of a 41 year-old male who came to the emergency room with a complaint of abdominal pain, and was diagnosed to have an acute obstructive abdomen due to a right inguinal hernia incarceration. During surgery, an intestinal granulomatous inflammation was observed adhered to the hernial sac. The histopathologic study confirmed the diagnosis of tuberculosis. We present a review of the different clinical forms of intestinal tuberculosis and the difficulties encounted in the differential diagnosis of such, emphasizing the uncommon presentation described in our patient.
\end{abstract}

UNITERMS: Abdominal tuberculosis. Acute abdomen. Inguinal hernia.

\section{INTRODUCTION}

$\mathrm{T}$ Juberculosis is a disease caused by Mycobacterium tuberculosis, and the intestinal form is less frequent than the pulmonary form as a cause of hospitalization, although it is not uncommon, especially in less developed countries. Necropsies reveal that 50-80 percent of patients with a pulmonary lesion and cavitations have an accompanying intestinal infection. Intestinal infection may occur through hematogenic spreading, through swallowing of infected sputum, or contiguity with peritoneal lesions. Morphologically, this appears in two forms, the ulcerative and the hypertrophic, the latter is more frequent when there is no pulmonary tuberculosis, occurring more frequently in the cecum and terminal ileum.

Address for correspondence:

Mellyssande Faccin

Faculdade de Medicina do ABC

Av. Príncipe de Gales, 821

Santo André/SP - Brasil - CEP 09060-650
This is a universal disease, with an incidence that is progressively rising due to Acquired Immunodeficiency Syndrome and to increasing poverty worldwide.

\section{CASE DESCRIPTION}

M.A.S., 41 year-old white male, had been having morning fever and diarrhea alternated with constipation for one month. He had also noticed an increase in volume of his inguinal hernia, which he had already been aware of. A few hours before being attended, he began experiencing intense abdominal pain, which caused him to go to the emergency room. At first physical examination, the patient presented a $38 \mathrm{C}$ armpit temperature with abdominal distention and diminished air-fluid sounds, a visible tumefaction in right inguinal area with signs of inflammation, and a presence of the Blumberg sign. There was no hepatic or splenomegalia. Laboratory exams 
revealed the following results: hemoglobin of $11.9 \mathrm{~g}$ percent; a 36 percent hematocrit; and 7200 leukocytes, of which three percent were bands, 83 percent were segmented, 2 percent were eosinophils, 9 were percent lymphocytes, and 3 percent were monocytes. The erythocytementation rate during the first hour was $80 \mathrm{~mm}$.

During surgery a thickened hernial sac was noted, which contained small intestine and multiple nodules that had caused its adherence to the deep inguinal ring and impeded its reduction. The patient underwent an exploratory laparotomy in which numerous white nodules in the peritoneum, liver, small intestine, stomach, and colon were observed. After resection of the hernial sac, the histological examination macroscopically revealed an elevated yellow lesion, $5 \mathrm{~cm}$ in length with a firm, white surface. There were no perforations or bowel stenosis. Microscopically, there were numerous granulomas formed by epitheloid cells and giant cells with peripheral nuclei. These lesions presented central caseous necrosis similar to tuberculoid granulomas. The patient received an antituberculosis scheme composed of isonyazid, rifampicin, and pirizinamid for 6 months, and presented good clinical and laboratorial evolution. After 6 months, the symptoms had disappeared, the hemogram was normal, the erythrocytedimentation rate was $10 \mathrm{~mm}$ in the first hour, and mucoprotein was $2 \mathrm{mg}$ percent.

\section{DISCUSSION}

A review of four recent articles on the surgical treatment of this condition, one of which was a prospective study ${ }^{3}$ and three of which were retrospective studies 1 . 2.4 agree, along general lines, about the clinical characteristics of this condition, thus creating the possibility of comparing them with this specific case. These studies show that the disease presents nonspecific signs and symptoms. Abdominal pain is the most frequent complaint, whether it be recent or more prolonged. Symptoms such as fever, anorexia and weight loss are also frequent, with their description usually coming from patients submitted to diagnostic surgery. The studies

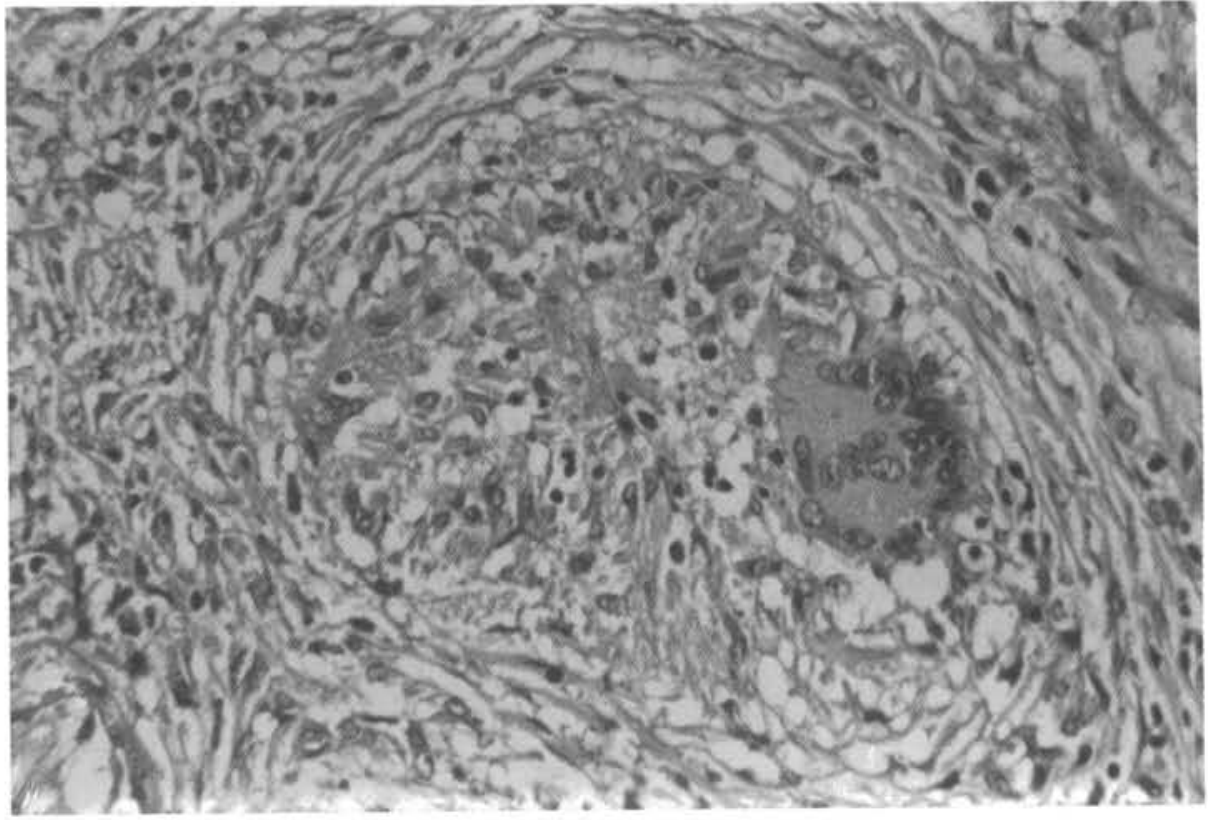

Figure 1 - Tuberculoid granuloma. Clear identification of a multi-nuclei giant cell. 200x. 
in only two. Definite diagnosis may be obtained by finding granulomas containing central caseous necrosis in the histopathologic material. In some cases there are suggestive lesions, although without necrosis. In these cases, histopathologic finding combined with clinical manifestations and a favorable evolution after tuberculosis treatment supports this diagnosis.

Several characteristics in our cases coincide with descriptions in the literature. As already mentioned, the absence of lung lesions in thoracic roentgenograms is very common, as well as high eriytrocyte sedimentation rates and the absence of leukocytosis. The tuberculoid granuloma that was found (Fig.1) suggested a diagnosis for such, confirmed by a good evolution after specific treatment. What may be an uncanny finding is that our patient, who underwent emergency surgery, may have presented bowel incarceration in the inguinal hernia as a result of the tuberculosis, since it was firmly adhered to the hernial sac, with no ulcerations, stenosis or perforations present. In fact, the latter is what leads to emergency surgery, while the hyperplastic form, as in our patient's case, is evidenced during elective laparotomy performed to differentrate this diagnosis from for a Crohn's disease or lymphoma. It is possible that had there been no adherence to the sac, and had the disease evolved for a longer time, diagnosis would have been made through routine investigation or elective laparotomy. As far as we know, there has been no reported case similar to this patient's, this being another uncommon form of presentation among numerous abdominal manifestations of this disease.

\section{ACKNOWLEDGMENTS}

The authors wish to thank Dr. Maria Regina Regis Silva, $\mathrm{PhD}$, head of the Discipline of Applied Pathology at the Federal University of São Paulo, and Maria Teresa Gianotti Gallupo, from the Discipline of Anatomical Pathology of the College of Medicine of the UFABC, for their help with the histological examinations and photographs.

\section{ReSUMo}

Relatamos um caso de paciente do sexo masculino, 41 anos, que deu entrada em Serviço de Emergência com queixa de dor abdominal, sendo feito diagnóstico de abdome agudo obstrutivo por encarceramento de hérnia inguinal à direita, A cirurgia, evidenciou-se alça intestinal com acometimento inflamatório granulomatoso, aderida ao saco herniário. O estudo anátomopatológico do material cirúrgíco confirmou o diagnóstico de tuberculose. Apresentamos uma revisāo sobre as diferentes formas clinicas da tuberculose intestinal e dificuldades encontradas para seu diagnóstico diferencial, enfatizando a inusitada forma de apresentação descrita em nosso paciente.

\section{REFERENCES}

1. Akinoglu A, Bilgin I. Tuberculous enteritis and peritonitis. Can J Surg 1988;31(1):55-8

2. Al-Hadeedi S, Walia HS, Al-Sayer HM. Abdominal tuberculosis. Can J Surg 1990;33(3):233-7.
3. Aston N O, De Costa AM. Abdominal tuberculosis. Br J Clin Pract 1990;44(2):58-63.

4. Underwood MJ, Thompson MN, Sayers RD, Hall AW. Presentation of abdominal tuberculosis to general surgeons. Br J Surg 1992;79:1077-9. 